
If you no longer need this publication write to the Geological Survey in Washington ror an
official mailing label to use in returning it

UNITED STATES DEPARTMENT OF THE INTERIOR

PALEOCENE FRESH-WATER MOLLUSKS FROM SOUTHERN MONTANA

GEOLOGICAL SURVEY PROFESSIONAL PAPER 214-C 






18



$$
\left.\frac{4}{4}+2 y^{2}\right)
$$



$=0$


,



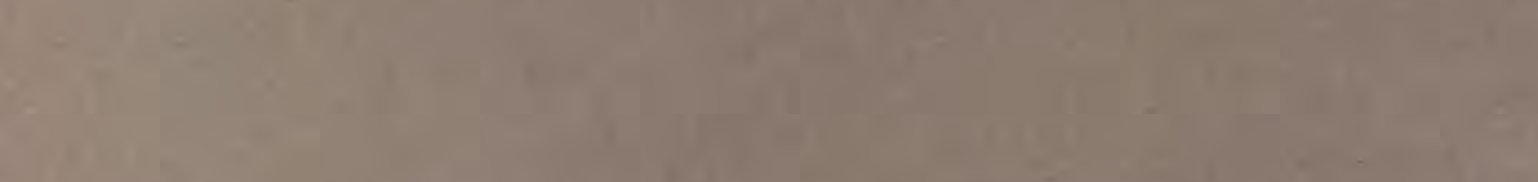



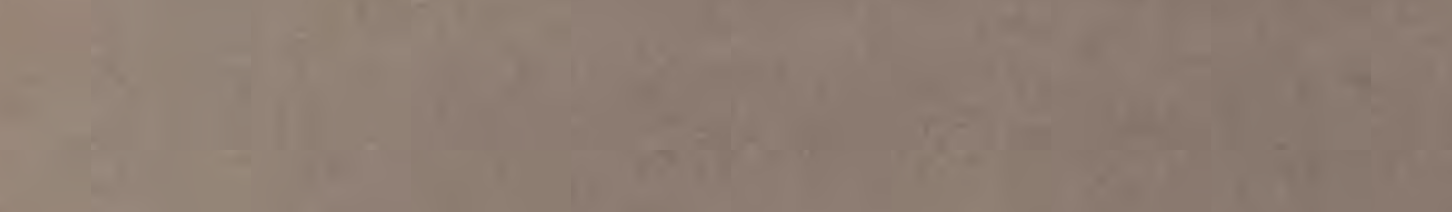

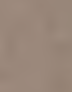




Bes


$=\operatorname{lin}(x)$
$1<-4$
$\lim _{2} \leq$
bit $\rightarrow=0$

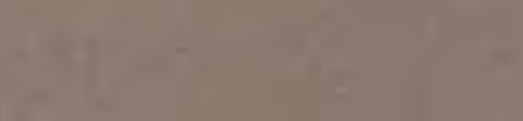
wath



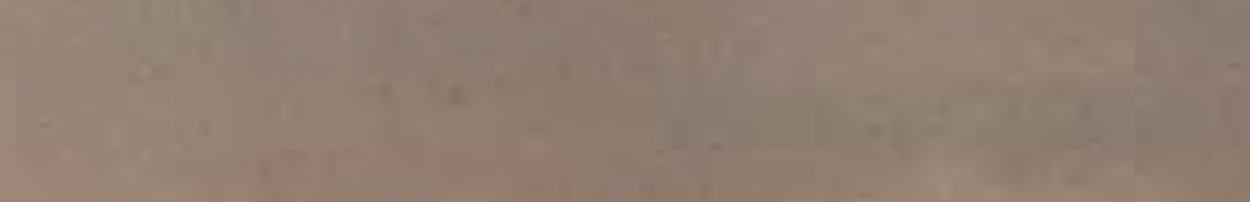
$=-6^{4}$

cha



ming in: 
UNITED STATES DEPARTMENT OF THE INTERIOR

J. A. Krug, Secretary

GEOLOGICAL SURVEY

W. E. Wrather, Director

Professional Paper 214-C

\title{
PALEOCENE FRESH-WATER MOLLUSKS FROM SOUTHERN MONTANA
}

\author{
BY \\ TENG-CHIEN, YEN \\ Shorter Contributions to General Geology, 1947 \\ (Pages 35-50)



UNITED STATES

Government PRINTING OFFICE

WASHINGTON : 1948

For sale by the Superintendent of Documents, U. S. Government Printing Office, Washington 25, D. C. Price 15 cents 


\section{CUNTENTS}

Abstract

Introduction

Previous work

Composition and ecologic significance of the fauna

Stratigraphic distribution and age of the fauna

Geographic distribution of the collections

Systematic descriptions

Bibliography

Index

\section{ILLUSTRATION}

Prate 10. Paleocene fresh-water mollusks from southern Montana. 


\title{
PALEOCENE FRESH-WATER MOLLUSKS FROM SOUTHERN MONTANA
}

\author{
By Teng-Chien Yen
}

\begin{abstract}
Twenty-two species of fresh-water mollusks (two new) are described and illustrated from $\mathbf{4 5}$ localities in southern Montana. The genera Viviparus, Campeloma, Lioplacodes, Fluminicola, Pleurocera, Goniobasis, Ferrissia, Palaeancylus (new), Pleurolimnaea, Physa, Aplexa, Gyraulus, Carinorbis, Sphaerium, and Elliptio are represented. The fauna comes mainly from the Tongue River member of the Fort Union formation and is assigned to the Paleocene, though it seems divisible into an older and a younger group of species and extends into beds that on other grounds are considered to belong to the Wasatch formation and to be of early Eocene age.
\end{abstract}

\section{INTRODUCTION}

During 1940 and 1941 R. P. Bryson, of the U. S. Geological Survey, assisted by W. H. Haas and F. S. MacNeil, obtained an interesting collection of fossil fresh-water mollusks from 45 localities in southern Montana. I have had the privilege of studying this large collection of generally well preserved specimens. The material was collected mainly at places in Powder River and Big Horn Counties, but a few lots were obtained in Rosebud County and a few at places in Wyoming a short distance south of the Wyoming-Montana boundary.

In completing this work, I wish to express my thanks to the administrative officers of the Geological Society of America for their continuous support in making a further grant from the Penrose Bequest to carry on the project. Thanks are also due Dr. John B. Reeside, Jr., of the U. S. Geological Survey, for his valuable suggestions and also for his untiring encouragement. To Dr. H. A. Pilsbry, of the Academy of Natural Sciences of Philadelphia, I am much indebted for his expert advice on my work, and I appreciate his personal interest.

\section{PREVIOUS WORK}

The earliest records of molluscan species from the Fort Union formation were made by Meek and Hayden from 1856 to 1861 . The following 25 species were reported from what they called then "the Lignite group" of the upper Missouri River. These species were redescribed and figured, with the exception of one or two forms, by Meek in 1876. The following list is in systematic order, though the original generic assignment is retained:

Valvata subumbilicata Meek and Hayden 1856

Valvata parvula Meek and Hayden 1856

792023-48
Ialvata montanaensis Meek 1876

Paludina retusa Meek and Hayden 1856

Paludina leai Meek and Hayden 1856

Paludina peculiaris Meek and Hayden 1856

Paludina trochiformis Meek and Hayden 1856

Paludina leidyi Meek and Hayden 1856

Viviparus leidyi var. formosus Meek 1876

Vivipara raynoldsana Meek and Hayden 1861

Bulimus nebrascensis Meek and Hayden 1856

Melania multistriata Meek and Hayden 1856

Melania nebrascensis Meek and Hayden 1856

Bulimus limnaeiformis Meek and Hayden 1856

Melania anthonyi Meek and Hayden 1856

Melania warrenana Meek and Hayden 1857

Hydrobia? eulimoides Meek 1876

Melania minutula Meek and Hayden 1856

Melania tenuicarinata Meek and Hayden 1857

Velletia (Ancylus) minuta Meek and Hayden 1856

Limnaea tenuicosta Meek and Hayden 1856

Physa longiuscula Meek and Hayden 1856

Physa rhomboidea Meek and Hayden 1856

Cyclas formosa Meek and Hayden 1856

Cyclas subellipticus Meek and Hayden 1856

Except for a few additional forms recorded in recent years, this earliest list of fresh-water mollusks from the Fort Union formation contains almost all the characteristic species of the formation. These species rere originally described from several casual collections of material, and the exact stratigraphic position of their occurrence within the formation is unknown. However, by checking with the records made in later years, it would seem that they were obtained from several horizons in North Dakota and Montana.

In $1886 \mathrm{C}$. A. White recorded most of the abovementioned species in the vicinity of Wales, Utah, although he assigned the fossiliferous beds to the "Wasatch group," which was then extended, probably unintentionally, to include at that place deposits of Fort Union age and even Cretaceous beds (Spieker, 1946, p. 134). Ten years later a number of these characterstic species were identified by T. W. Stanton among sfacimens collected from the eastern slope of the Crazy Mountains on Lebo Creek, Mont. (Weed, 1896, p. 276), where they are found in limestone, shale, and sandstone of the Fort Union formation of that area. In 1931 L. S. Russell recorded six of these species from Fort Union strata exposed in Park County, northwestern Wyoming. In $1946 \mathrm{I}$ gave a record of nine species of fresh-water mollusks from a horizon just above the commonly accepted base of the Wasatch formation 
(Roland coal bed) in Sheridan County, Wyo., the majority of which are species of the Fort Union formation.

\section{COMPOSITION AND ECOLOGIC SIGNIFICANCE OF THE FAUNA}

The generic assignment of some of the species described in the literature needs revision, and a few changes are proposed in this paper. Paleontologic data indicate that many genera of fresh-water mollusks have a long range in geologic history, and some of the common genera of the living fauna may be traced back to much earlier ages. However, it is difficult to make a precise decision as to proper allocation of species when some of the "catch-all" genera are involved. A thorough study of these groups of fresh-water mollusks will provide opportunity for an important contribution by anyone interested in this vast field of knowledge.

A summary list of the species here identified is as follows:

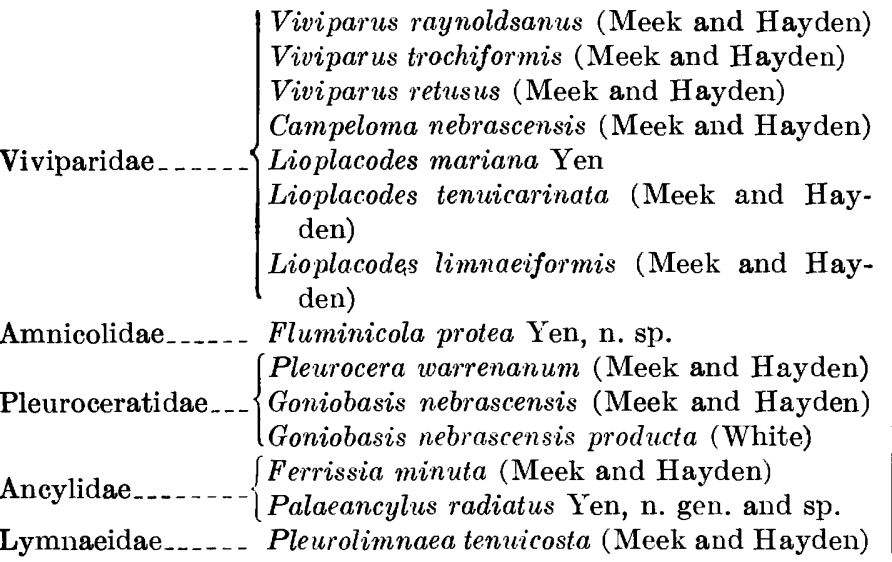

Physidae $\quad$ Physa ef. P. bridgerensis Meek Aplexa cf. A. longiuscula (Meek and Hayden) Gyraulus militaris (White)

Planorbidae.....- $\{$ Gyraulus parvulus (Meek and Hayder) Carinorbis planospiralis Yen

Sphaeriidae..... Sphaerium ef. S. formosum (Meek and Hayden)

Unionidae _.... $\left\{\begin{array}{l}\text { Elliptio ef. E. priscus (Meek and Hayden) } \\ \text { Elliptio ef. E. silberlingi Russell } \\ \text { "Unio" sp. undet. }\end{array}\right.$

The abundant occurrence of viviparids and unins implies that the enclosing rocks were fluviatile deposits. These forms in the living fauna exist more commonly in rivers and streams of various sizes. The presence of abundant shells of fresh-water pulmonates in a number of the lots, such as that from locality 17 , implies perhaps a shore facies of the river deposits, where the water was shallow and rich aquatic vegetation graw.

\section{STRATIGRAPHIC DISTRIBUTION AND AGE OF THE FAUNA}

The accompanying table shows the distribution of the molluscan species in the intervals between the successive coal beds of the region. The generalized section is taken from the report of A. A. Baker (1929, pp. 33-38) on the northward extension of the Sheridan coal field into Big Horn and Rosebud Counties, southern Montana.

It is to be noted that the level commonly accepted as the boundary between the Tongue River member of the Fort Union formation, assigned to the Paleocene, and the Wasatch formation, assigned to the lower Eocene, is the top of the Roland coal bed, though there is every

Distribution of species by number of localities in each interval between coal beds

\begin{tabular}{|c|c|c|c|c|c|c|c|c|c|c|c|c|c|c|c|c|c|c|c|c|c|c|c|c|}
\hline $\begin{array}{l}\text { Generalized sequence of the coal beds and barren } \\
\text { intervals, after A. A. Baker (1929, pp. 33-38) }\end{array}$ & $\begin{array}{l}\text { Thick- } \\
\text { ness } \\
\text { (feet) }\end{array}$ &  & 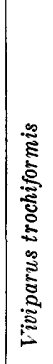 & 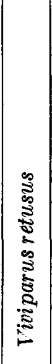 &  &  &  &  &  & 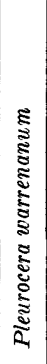 &  & 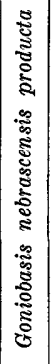 & 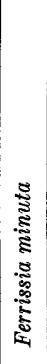 & 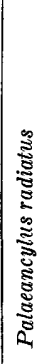 & 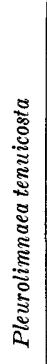 & 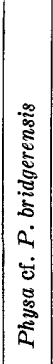 & 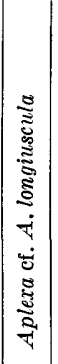 & 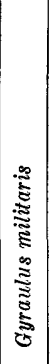 & 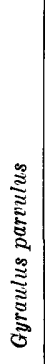 & 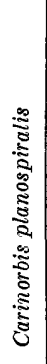 & 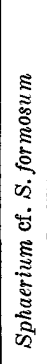 & 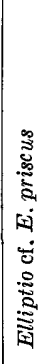 & 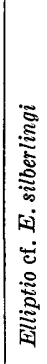 &  \\
\hline $\begin{array}{l}\text { Part of Wasatch formation: } \\
\text { Badger coal bed........ }\end{array}$ & $0-7$ & & & & & & & & & & & & & & & & & & & & & & & \\
\hline $\begin{array}{l}\text { Interval } \\
\text { Local coal bed.-................. }\end{array}$ & $\begin{array}{l}180 \\
0-5 \\
180\end{array}$ & & 5 & & & 9 & 4 & 5 & $\ldots$ & 7 & & & & & & & & $\ldots$ & 1 & 6 & .... & 4 & 1 & 1 \\
\hline 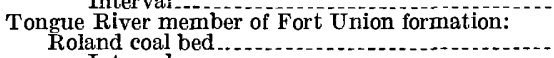 & $0-13$ & & & & & & & & & & & & & & & & & & & & & & & \\
\hline Interval-ad & 195 & 1 & 7 & & & 7 & 1 & 3 & & 1 & & & & & & & & 2 & 2 & 1 & $\ldots$ & 1 & 1 & \\
\hline $\begin{array}{l}\text { Smith coal bed.. } \\
\text { Interval }\end{array}$ & $\begin{array}{l}0-200 \\
70\end{array}$ & 3 & 2 & & & 7 & 7 & 6 & 1 & $\cdots$ & & .. & 1 & 1 & 1 & 1 & 1 & 1 & 3 & $\ldots$ & 1 & 2 & & $-\cdots$ \\
\hline $\begin{array}{l}\text { Powers coal bed } \\
\text { Inter val }\end{array}$ & $\begin{array}{r}0-10 \\
60\end{array}$ & 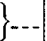 & 1 & & $\cdots$ & 1 & $\cdots$ & 1 & & & & -. & & & $\cdots$ & $\cdots$ & & & & & $\ldots$ & & & $\cdots$ \\
\hline $\begin{array}{l}\text { Anderson coal bed..... } \\
\text { Interval }\end{array}$ & $10-27$ & 1 & $\ldots$ & $\ldots$ & & 1 & 2 & 2 & & & & & & & & & & & & & & & & \\
\hline Dietz No. 1 coal bed. & $0-16$ & 1 & & & & 1 & 1 & & & & & & & & & & & & & & & & & \\
\hline $\begin{array}{l}\text { Interval } \\
\text { Canyon coal bed. }\end{array}$ & $6-20$ & 2 & & & & 2 & 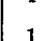 & 1 & & & & & & & & & & & & & & 2 & & \\
\hline $\begin{array}{l}\text { Interval } \\
\text { Wall coal bed }\end{array}$ & $180-230$ & & & & & & & & & & & & & & & & & & & & & & & \\
\hline - & $\begin{array}{c}0-32 \\
235\end{array}$ & I & ... & 1 & 2 & 1 & $\cdots$ & 2 & & & $\cdots$ & 1 & & & & & & & & & .... & 1 & 1 & \\
\hline Brewster-Arnold coal bed. & $10-17$ & & & $\ldots$ & 1 & & & 1 & & & 1 & 1 & & & & & & & & & 1 & & & \\
\hline $\begin{array}{l}\text { Interval } \\
\text { Knoblock coal bed................. }\end{array}$ & $\begin{array}{l}170 \\
20\end{array}$ & & & & & & & & & & & & & & & & & & & & & & & \\
\hline Interva & 396 & & & & $\cdots$ & & -- & $\cdots$ & & & & & & & & & & & & & & & & \\
\hline
\end{tabular}


appearance in southern Montana of continuity of deposition across this level. The reason for using the top of the Roland coal bed is that it is a readily traceable plane and that it is believed to lie near the stratigraphic position of the base of the Kingsbury conglomerate member of the Wasatch formation of the western margin of the Powder River Basin of Wyoming (Thom and Dobbin, 1924). The Kingsbury conglomerate has yielded mammals of the genera Hyracotherium and Coryphodon (Wegemann, 1918; Brown, 1948), which are accepted as establishing its Eocene age. The extensive flora and vertebrate fauna of the Fort Union formation establish it as of Paleocene age.

Most of the fresh-water mollusks contained in the present collection are species originally described from the Fort Union formation. Characteristic and common Upper Cretaceous species, such as Tulotoma thompsoni White, "Melania" insculpta Meek, and "Melania" wyomingensis Meek, are conspicuously absent. On the other hand, several forms of so-called Goniobasis, widely reported from deposits of Wasatch age, are also lacking. The present fauna therefore seems clearly to represent a distinct unit different from that of the Lance formation or that of the Wasatch formation of other areas. Furthermore, both the Lance and the Wasatch formations are probably of fluviatile origin and the differences between the faunas of these two formations and that of the Fort Union would seem to be due to difference in age rather than to some difference in conditions of deposition.

Within the present fauna it is possible to distinguish between the assemblage above the Wall coal bed and that below it. The difference is not striking, however, and it is undetermined whether it is persistent into other regions and will be useful in determining relative stratigraphic position.

The lots recorded from the beds above the Wall coal bed seem to contain a more or less similar group of species. Each lot contains a few of the following characteristic forms:

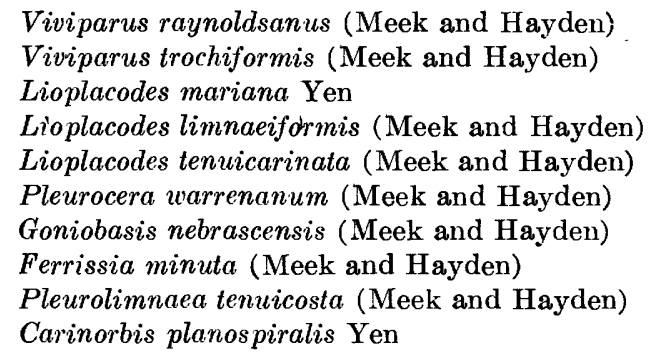

On the other hand, collections made below the Wall coal bed differ by the presence of Campeloma nebrascensis (Meek and Hayden) and Goniobasis nebrascensis (Meek and Hayden) and its variety or subspecies producta (White), which have not been found in the beds above the Wall coal. In previous records these three forms were described or reported from deposits variously assigned to the Laramie (in the strict sense), Lance, and Fort Union formations without mention of exact stratigraphic position within the several formations, and little help can be obtained from these records for the purpose of correlating the present collections. However, it seems to be a fact that these forms are found only in strata occupying positions lower than the upper part of the Fort Union formation. Whether these forms will justify a separation of the containing rocks a" an age unit distinct from the main body of the Fort Union formation will have to depend on further collections of material to demonstrate how persistent their occurrence is in these lower beds.

\section{GEOGRAPHIC DISTRIBUTION OF THE COLLECTIONS}

The collections represent 45 localities, mainl in Tps. 7, 8, and 9 S., Rs. 44 to 49 E., but with a few farther south and east. The horizons represented extend through a thickness of about 1,000 feet. A descrip tion of each locality and a list of the species at each follow:

Locality 1.-The NE1/4 sec. 2, T. 7 S., R: 44 E., Rosebud County; at the base of a steep butte, more than 200 feet above the Anderson clinker.

Viviparus ef. $V$. raynoldsanus (Meek and Hayden)

Lioplacodes mariana Yen

Lioplacodes limnaeiformis (Meek and Hayden)

"Unio"sp.

Locality 2.-Southwest of center sec. 7, T. 9 S., R. 44 E., Big Horn County; exposure just above Roland coal bed.

Viviparus sp. undet.

Lioplacodes ef. L. mariana Yen

Lioplacodes limnaeiformis (Meek and Hayden)

Pleurocera warrenanum (Meek and Hayden)

Elliptio cf. E. priscus (Meek and Hayden)

"Unio"sp.

Locality 3.-Southeast of center sec. 7, T. 9 S., R. 44 E., Big Horn County; sandstone ledge below Roland coal bed.

Lioplacodes mariana Yen

Elliptio cf. E. priscus (Meek and Hayden)

"Unio" sp.

Locality 4.-The SE1/4 sec. 8, T. 9 S., R. 44 E., Big Horn County; about 130 feet above the Smith coal bed.

Viviparus trochiformis (Meek and Hayden)

Lioplacodes mariana Yen

Elliptio cf. E. silberlingi Russell

Locality 5.-The SE1/4 sec. 30, T. 9 S., R. 44 E., Big Horn County; about 50 feet above the Roland coal bed.

Viviparus trochiformis (Meek and Hayden)

Lioplacodes mariana Yen

Lioplacodes tenuicarinata (Meek and Hayden)

Lioplacodes limnaeiformis (Meek and Hayden)

Pleurocera warrenanum (Meek and Hayden)

Elliptio cf. E. priscus (Meek and Hayden) 
Locality 6.-West of center sec. 35, T. 9 S., R. 44 E., Big Horn County; in and below the fossiliferous sandstone ledge above the Roland coal horizon.

Viviparus trochiformis (Meek and Hayden)

Lioplacodes mariana Yen

Elliptio cf. E. priscus (Meek and Hayden)

"Unio" sp. undet.

Locality 7.- Montana-Wyoming boundary line; about $1 / 4$ mile southeast from southeast corner of sec. 35 , T. 9 S., R. 44 E., Big Horn County; just above a fossiliferous sandstone ledge in soft buff sand.

Viviparus sp. undet.

Lioplacodes mariana Yen

Lioplacodes tenuicarinata (Meek and Hayden)

Pleurocera warrenanum (Meek and Hayden)

Gyraulus militar is (White)

Gyraulus parvulus (Meek and Hayden)

Carinorbi, planospiralis Yeu

"Unio" sp.

Locality 8.-In Sheridan County, Wyo., just across State boundary from SW $1 / 4$ sec. 23, T. 9 S., R. 45 E., Montana; on hillside 100 feet above the Wall coal bed of Warren.

I'iviparus sp.

Lioplacodes sp.

"Unio"sp.

Locality 9.-The NW1/4 sec. 25 , T. 7 S., R. 45 E., Powder River County; 108 feet above the Wall coal bed.

Lioplacode. mariana Yen

Lioplacodes limnaeiformis (Meek and Hayden)

"Unio" sp.

Locality 10.- The $\mathrm{SW}_{1 / 4}^{1 / \mathrm{SE}_{1 / 4}^{1 / S W} 1 / 4}$ sec. 9, T. 8 S., R. 45 E., Powder River County; just south of east-west fault and below a stump bed; 25 to 50 feet below the Smith coal bed.

Tiviparus trochiformis (Meek and Hayden)

Lioplacodes mariana Y'en

"Unio" sp.

Locality 11.- The NW1/4 sec. 12, T. 9 S., R. 45 E., Powder River County; sandstone ledge below Roland coal bed.

Lioplacodes ef. L. mariana Yen

Lioplacodes limnaeiformis (Meek and Hayden)

"Unio" sp. undet.

Locality 12.-The SE $1 / 4$ sec. 13, T. 9 S., R. 45 E., Powder River County; roof of Roland coal bed.

Viviparus sp.

Lioplacodes mariana Yen

Pleurocera warrenanum (Meek and Hayden)

Carinorbis planospiralis Yen

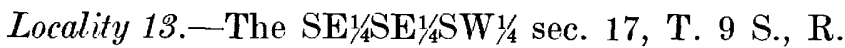
45 E., Powder River County; about 35 feet above the Roland coal bed.

Viviparus cf. I'. trochiformis (Meek and Hayden)

Lioplacodes mariana Yen
Lioplacodes tenuicarinata (Meek and Hayden) Lioplacodes limnaeiformis (Meek and Hayden) Pleurocera warrenanum (Meek and Hayden) Carinorbis planospiralis Yen

Locality 14.-The NW1/4 sec. 3, T. 7 S., R. 46 E., Powder River County; about 75 feet below the Wall coal bed.

Viviparus sp. undet.

"Unio" sp.

Locality 15.-South edge of $\mathrm{SE}_{1 / 4}^{1 / 4}$ sec. $21, \mathrm{~T}$. S., R. 46 E., Powder River County; 20 to 50 feet below the Canyon coal bed.

Tiviparus raynoldsanus (Meek and Hayden)

Lioplacodes cf. L. mariana Yen

Elliptio cf. E. priscus (Meek and Hayden)

Elliptio cf. E. silberlingi Russell

Locality 16.-The NE $\frac{1 / 4}{4} \mathrm{SE}_{1 / 4}^{1 / 4}$ sec. 32 , T. 8 S., R. 46 E., Powder River County; 6 to 12 feet above the Anderson coal bed.

Tiviparus trochiformis (Meek and Hayden)

Lioplacodes mariana Yen

Lioplacodes limnaeformis (Meek and Hayden)

Carinorbis sp. undet.

"Unio"sp.

Locality 17.-300 feet east from the southeast corner sec. 32, T. 8 S., R. 46 E., Powder River County; 100 feet above base of Anderson clinker.

I'iviparus sp. undet.

Fluminicola protea n. sp.

Lioplacodes tenuicarinata (Meek and Hayden)

Lioplacodes limnaeiformis (Meek and Hayden)

Lioplacodes sp. undet.

Ferrissia minuta (Meek and Hayden)

Palaeancylus radiatus n. sp.

Pleurolimnaea tenuicosta (Meek and Hayden)

Physa cf. P. bridgerensis Meek

Aplexa cf. A. longiuscula (Meek and Hayden)

Carinorbis sp. undet.

Sphaerium sp. undet.

Locality 18.-The SE1/4E1/4NW1/4 sec. 18, T. 9 S., R. 46 E., Powder River County; about 25 feet above the base of Roland clinker.

Viviparus trochiformis (Meek and Hayc'en)

Lioplacodes mariana Yen

Lioplacodes limnaeiformis (Meek and Hayden)

Pleurocera warrenanum (Meek and Hayden)

Carinorbis planospiralis $\mathrm{Yen}$

Gyraulus parvulus (Meek and Hayden)

"Unio" sp.

Locality 19.-The NW1/4 NW1/4 sec. 28, T. 9 S., R. 46 E., Powder River County; 50 to 75 feet below the Roland coal bed.

Viviparus ef. V. trochiformis (Meek and Hayden)

Lioplacodes mariana Yen

Pleurocera warrenanum (Meek and Hayden)

Gyraulus militaris (White)

Gyraulus parvulus (Meek and Hayden)

"Unio" sp. 
Locality 20.-The SW $1 / 4 \mathrm{NW}_{14}^{1 / 1}$ sec. 31 , T. 9 S., R. 46 E., Powder River County; gray shale, 1 foot above the Roland coal bed.

Viviparus ef. Ir. trochiformis (Meek and Hayden)

Lioplacodes mariana Yen

Lioplacodes limnaeiformis (Meek and Havden)

Pleurocera warrenanum (Meek and Hayden)

Carinorbis planospiralis. Yen

Elliptio ef. E. priscus (Meek and Hayden)

Locality 21.-About 1,100 feet west of southeast corner sec. 30, T. 9 S., R. 46 E., Powder River County; about 10 feet above the Dietz coal bed.

Lioplacodes tenuicarinata (Meek and Hayden)

Lioplacodes limnaeiformis (Meek and Hayden)

Locality 22.- - Near Montana-Wyoming boundary, about 300 feet northeast of southeast corner sec. 32, T. 9 S., R. 46 E., Powder River County; 50 to 75 feet below Roland coal bed.

riviparus sp. undet.

Lioplacodes ef. L. mariana Yen

Lioplacodes tenuicarinata (Meek and Hayden)

Lioplacodes limnaeiformis (Meek and Hayden)

"Unio" sp.

Locality 23.-Montana-Wyoming boundary, near southeast corner sec. 36, T. 9 S., R. 45 E.; about 150 feet south of the boundary line and 60 feet below base of Roland coal bed.

Viviparus trochiformis (Meek and Hayden)

Lioplacodes cf. L. mariana Yen

Lioplacodes tenuicarinata (Meek and Hayden)

Gyraulus parvulus (Meek and Hayden)

Elliptio cf. E. priscus (Meek and Hayden)

Locality 24.-The NE $1 \frac{1}{4} \mathrm{SE} 1 \frac{1}{4} \mathrm{sec} .1$, T. 7 S., R. 47 E., Powder River County; about 2 miles northeast of Diamond Butte triangulation station; between Dietz and Anderson coal beds.

Viviparus raynoldsanus (Meek and Hayden)

Lioplacodes mariana Yen

Lioplacodes tenuicarinata (Meek and Hayden)

Lioplacodes limnaeiformis (Meek and Hayden)

"Unio"sp.

Locality 25.-East of center sec. 4, T. 7 S., R. 47 E., Powder River County; 25 to 30 feet below the Dietz coal bed.

Tivipar us raynoldsanus (Meek and Hayden)

Lioplacodes mariana Yen

"Unio" sp.

Locality 26.-The NW1/4 sec. 11, T. 7 S., R. 47 E., Powder River County; about 130 feet above the Anderson coal bed.

"Unio" sp.

Locality 27.-Center sec. 36, T. 7 S., R. 47 E., Powder River County; 40 to 50 feet below the Diamond bed.

Viviparus raynoldsanus (Meek and Hayden)

Lioplacodes mariana Yen
Lioplacodes tenuicarinata (Meek and Hayden) Lioplacodes limnaeiformis (Meek and Hayden) Elliptio cf. E. priscus (Meek and Hayden

Locality 28.-About 1,100 feet east of southwest corner sec. 19, T. 8 S., R. 47E., Powder River County; about 25 feet above the Smith coal bed.

"Unio" sp.

Locality 29.-The NW1/4SW1/4 sec. 28, T. 8 S., R. 47 E., Powder River County; about 165 feet above the Snith coal bed.

Tiviparus trochiformis (Meek and Hayden)

Lioplacodes mariana Yen

Lioplacodes limnaeiformis (Meek and Hayden)

Gyraulus militaris White

Gyraulus parvulus (Meek and Hayden)

Carinorbis planospiralis Yen

Elliptio ef. E. priscus (Meek and Hayden)

Elliptio ef. E. silberlingi Russell

Locality 30.-The SW1/4SE1/4 sec. 34, T. 8 S., R. 47 F., Powder River County; about 70 feet below $\mathrm{L}$ :etz clinker.

"Unio"spp.

Locality 31.-About 700 feet from southeast coner sec. 13, T. 8 S., R. 46 E., Powder River County; 25 to 50 feet below the Smith bed.

Tiviparus sp. undet.

Lioplacodes mariana Yen

"Unio" sp.

Locality 32.-The NW $1 / 4 \mathrm{NE}^{1 / 4}$ sec. 5, T. 9 S., R. 47 E., Powder River County; 150 to 200 feet above the Anderson coal bed.

Viviparus trochiformis (Meek and Hayden)

Lioplacodes mariana Yen

Lioplacodes tenuicarinata (Meek and Hayden)

"Unio"sp.

Locality 33.-About 300 feet northeast from southwest corner sec. 17, T. 9 S., R. 47 E., Powder River County; about 150 feet above the Anderson coal kad.

Viviparus trochiformis (Meek and Hayden)

Lioplacodes mariana Yen

Lioplacodes limnaeiformis (Meek and Hayden)

"Unio" sp.

Locality 34.-Center NE1/4 sec. 23, T. 9 S., R. 47 E., Powder River County; about 50 feet below the Canyon coal bed.

Viviparus ef. V. raynoldsanus (Meek and Hayden)

Lioplacodes tenuicarinata (Meek and Hayden)

Elliptio ef. E. priscus (Meek and Hayden)

Locality 35.-The NE ${ }^{1 / 4} \mathrm{SE}_{1 / 4}^{1 / 4}$ sec. 31, T. 9 S., R. 47 E., Powder River County; about 150 feet above the Anderson coal bed.

Viviparus trochiformis (Meek and Hayden)

Lioplacodes mariana Yen

"Unio" sp. 
Locality 36.-SE $1 / 4 \mathrm{SE}_{1 / 4}^{1 / 4}$ sec. 32 , T. 9 S., R. 47 E., Powder River County; about 135 feet above the Anderson coal bed.

Viviparus trochiformis (Meek and Hayden)

Lioplacodes tenuicarinata (Meek and Hayden)

Locality 37.-The NE $1 / 4 \mathrm{NW}_{14}^{1}$ sec. 32 , T. 8 S., R. 48 E., Powder River County; about 100 feet above the base of Canyon coal.

Viviparus ef. $V$. raynoldsanus (Meek and Hayden) Lioplacodes mariana Yen

Lioplacodes cf. L. tenuicarinata (Meek and Hayden)

Elliptio ef. E. priscus (Meek and Hayden)

Locality 38.-The SW $1 / 4 \mathrm{SW}_{1 / 4}$ sec. 6, T. 9 S., R. 48 E., Powder River County; about 100 feet above the base of Canyon coal bed.

Elliptio cf. E. priscus (Meek and Hayden)

Locality 39.-T. 2 S., R. 49 E., Powder River County; about 180 feet above the Brewster-Arnold bed.

Viviparus retusus (Meek and Hayden)

Lioplacodes limnaeiformi: (Meek and Hayden)

Campeloma nebrascensis (Meek and Hayden)

Goniobasis nebrascensis producta (White)

"Unio" sp.

Locality 40.-The $\mathrm{NW}_{14}^{1 / 4}$ sec. 31 , T. 9 S., R. 49 E., Powder River County; about 125 feet above the Anderson coal bed.

Viviparus raynoldsanus (Meek and Hayden)

Lioplacodes mariana Yen

Lioplacodes tenuicarinata (Meek and Hayden)

Lioplacodes limnaeiformis (Meek and Hayden)

Gyraulus militaris (White)

Gyraulus parvulus (Meek and Hayden)

Sphaerium sp. undet.

"Urio" spp.

Locality 41.-The SE $1 / 4$ sec. 31 , T. 9 S., R. 49 E., Powder River County; about 100 feet above the Anderson coal bed.

Viviparus raynoldsanus (Meek and Hayden)

Lioplacodes mariana Yen

Lioplacodes tenuicarinata (Meek and Hayden)

Lioplacodes limnaeiformis (Meek and Hayden)

Gyraulus parvulus (Meek and Hayden)

"Unio"sp.

Locality 4R.-The SW $1 / 4 \mathrm{SE} 1 / 4$ sec. 4, T. 7 S., R. 50 E., Powder River County; about 12 feet above a local bed below the Cache coal bed.

Campeloma nebrascensis (Meek and Hayden)

Lioplacodes limnaeiformis (Meek and Hayden)

Goniobasis nebrascensis (Meek and Hayden)

Goniobasis nebrascensis producta (White)

Sphaerium sp. undet.

"Unio" sp.

Locality 43.-West edge sec. 32 , T. 1 S., R. 51 E., Powder River County; reworked specimens in a terrace deposit capping a high ridge of uppermost somber beds.

Viviparus retusus (Meek and Hayden)

Campeloma nebrascensis (Meek and Hayden)

Goniobasis nebrascensis producta (White)

"Unio" sp.
Locality 44.-Center S1/2 sec. 30, T. 9 S., R. 51 E., Powder River County; about 75 feet above the Cache coal bed.

Campeloma nebrascensis (Meek and Hayden)

Lioplacodes limnaeformis (Meek and Hayden)

"Unio" sp.

Locality 45.-Sec. 24, T. 58 N., R. 77 W., W!roming; about 50 to 75 feet below the Roland coal bed.

Viviparus trochiformis (Meek and Hayden)

Lioplacodes mariana Yen

"Unio" sp.

\section{SYSTEMATIC DESCRIPTIONS}

Family VIVIPARIDAE

Viviparus raynoldsanus (Meek and Hayden)

Plate 10, figure 1

Vivipara raynoldsana Meek and Hayden, Acad. Nat. Sri. Philadelphia Proc., vol. 13, p. 446, 1861.

This species is recorded here by rather forfectly preserved specimens from five localities. The whorls are greatly convex and bear growth and spirs.l lines. The development of spiral striae varies from obsure to faintly traceable, and they are never prominent. It is easily distinguished from the next species by the outline of shell and sculpture. The illustrated specimen measures $45 \mathrm{~mm}$. in altitude and $30 \mathrm{~mm}$. in width of the shell, $22 \mathrm{~mm}$. in height and $16.2 \mathrm{~mm}$. in width of aperture, and has $61 \frac{1}{2}$ whorls.

Plesiotype, U. S. Nat. Mus. 560162.

Viviparus trochifor mis (Meek and Hayden)

Plate 10, figures 2, 2a

Paludina trochiformis Meek and Hayden, Acad. Nat. Eci. Philadelphia Proc., vol. 8, p. 122, 1856.

This species was described on the basis of an immature specimen. Specimens corresponding to a similar stage of development are found in the present collection, together with a large series of adult specimers. The sculpture is prominent and consists of 4 to 5 primary spiral lines with secondary ones in the interspaces. The shell also bears very distinct lines of growth. The differences of sculpture on the shells of viviparids generally indicate the different development of the marginal processes of the mantle on the embryos of different species, and they are generally considered to be good specific characters, particularly in Viviparus, the species of which vary, often considerably, in general outline, size, and shape of aperture. The figured specimen measures $40.5 \mathrm{~mm}$. in altitude and $2 ? .5 \mathrm{~mm}$. in width of shell, $16.7 \mathrm{~mm}$. in height and $15 \mathrm{~mm}$. in width of aperture, and has 7 whorls.

Plesiotypes, U. S. Nat. Mus. 560163.

Viviparus retusus (Meek and Hayden)

Plate 10, figure 3

Paludina retusa Meek and Hayden, Acad. Nat. Sci. Philadelphia Proc., vol. 8, p. 122, 1856. 
A few specimens from localities 39 and 43 are identical with this species. It is characterized by its scarcely convex whorls, angulated periphery, and closed umbilicus.

Plesiotype, U. S. Nat. Mus. 560164.

\section{Campeloma nebrascensis (Meek and Hayden) \\ Plate 10, figures 4, 4a, 5, 5a, b}

Bulimus nebrascensis Meek and Hayden, Acad. Nat. Sci. Philadelphia Proc., vol. 8, p. 118, 1856.

This species is recorded here from two localities in the lower part of the formation. It is characterized by its shell substance, inflated body whorl, and thickened inner lip margin. Some shells, probably males, have a less inflated body whorl, which gives a narrower outline to the shell. The spiral lines are faintly traceable in a few specimens in this collection. The measurements in millimeters of two specimens are as follows:

\begin{tabular}{l|c|c}
\hline & & $33.0+$ \\
Altitude of shell & 28.5 \\
Width of shell & 18.2 & 16.5 \\
Height of aperture & 14.0 & 13.8 \\
Width of aperture & 9.0 \\
Number of whorls & $5+$ & 5 \\
\hline
\end{tabular}

Plesiotypes, U. S. Nat. Mus. 560165, 560166.

\section{Lioplacodes mariana Yen}

Plate 10, figures $6,6 a, b, c$

Lioplacodes mariana Yen, Am. Jour. Sci., vol. 224 , No. 1, p. 44 pl. 1, figs. 5a-c, 1946.

This species has been recorded, I believe, in the early literature under Lioplax nebrascensis or Goniobasis nebrascensis. However, it is readily distinguished from that species, as I have already pointed out elsewhere. It seems to be a common species of the Fort Union formation, and in several localities it is found in association with the next species.

There are specimens in the collection having a narrower outline of the shell, though the other features are essentially identical with those of the broader form.

The measurements in millimeters for four specimens of different developmental stages are as follows:

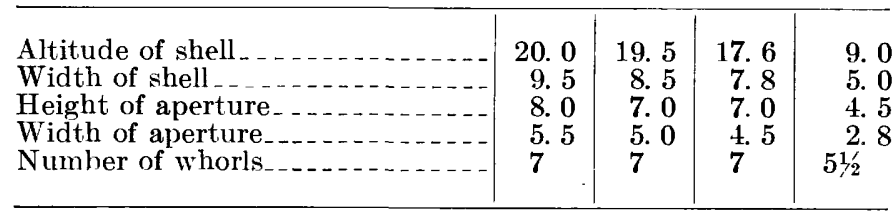

Plesiotypes, U. S. Nat. Mus. 560168, 560169, 560170.

\section{Lioplacodes tenuicarinata (Meek and Hayden)}

Plate 10, figures 7, 7a-d

Melania tenuicarinata Meek and Hayden, Acad. Nat. Sci. Philadelphia Proc., vol. 9, p. 137, 1857.

This species was described on the basis of a young shell, which one of the specimens figured here resembles very closely. The adult specimens reach a much larger 792023-48-2 size and bear a narrowly open umbilicus. It difers from the preceding species by having distinct spiral sculpture in young specimens as well as in the adult ones.

The measurements in millimeters for two examples are as follows:

\begin{tabular}{l|r|r}
\hline Altitude of shell & $21.7+$ & 15.6 \\
Width of shell & $\begin{array}{r}11.0 \\
\text { Height of aperture }\end{array}$ & $\mathbf{7 . 8}$ \\
Width of aperture & 6.5 \\
Number of whorls & $51 / 2+$ & 4.2 \\
\hline
\end{tabular}

Plesiotypes, U. S. Nat. Mus. 560171, 560172.

\section{Lioplacodes limnaeiformis (Meek and Hayden)}

Plate 10, figure 11

Bulımus limnaeiformis Meek and Hayden, Acad. Nat. Sci. Philadelphia Proc., vol. 8, p. 118, 1856.

This is one of the more characteristic forms in the Fort Union formation. It is easily recognized by its narrowly oblong outline, tapering gradually toward the apex, its scarcely convex whorls, and its narrowly perforated umbilicus. One of the well-preserved spacimens is $20 \mathrm{~mm}$. in altitude and $8 \mathrm{~mm}$. in width of the shell, $8 \mathrm{~mm}$. in height and $4.1 \mathrm{~mm}$. in its width of aperture, and has 7 whorls.

Plesiotype, U. S. Nat. Mus. 560173.

\section{Family AMNICOLIDAE \\ Fluminicola protea Yen, n. sp.}

Plate 10, figure 12

Shell broadly ovate in outline, of thin substance, having an elevated spire and moderately dilated body whorl. Whorls increasing rapidly in size, convex, and bearing fine but distinct lines of growth and spiral striae. Aperture subovate in outline, apparently having a thin peristomal margin.

The measurements in millimeters of the holotype and paratype are as follows:

\begin{tabular}{l|l|l}
\hline Altitude of shell & 8.5 & $\mathbf{7 . 0}$ \\
Width of shell & 6.3 & 5.7 \\
Number of whorls & $43 / 4$ & 4 \\
\hline
\end{tabular}

This form has all the features of Fluminicola, speries of which are recorded so far from Pliocene to Recent time in North America. I find no valid reason vrhy Fluminicola could not have preceded the Pliocene, even though the relationship of the present species to others of the genus is not clear at present.

One of the specimens here has its operculum partly preserved in its natural position, and this seems to be much like the type of operculum in Viviparus.

Holotype, U. S. Nat. Mus. 560174; paratypes, U. S. Nat. Mus. 560175 . 


\section{Family PLEUROCERATIDAE}

Pleurocera warrenanum (Meek and Hayden)

Plate 10, figure 8

Melania warrenana Meek and Hayden, Acad. Nat. Sci. Philadelphia Proc., vol. 9, p. 137, 1857.

The type of this species has the last 6 whorls preserved, and possibly would have 7 , if perfect. Some of the larger specimens in the present collection have 8 to $8 \frac{1}{2}$ whorls, but they are identical with the type in other features. The species is characterized by the scarcely convex or nearly flat surface of the early whorls, which are acutely angulated. The angulation is obtuse only along the periphery.

Meek was not certain of the generic position of the species. It was originally described as Melania and subsequently changed to Hydrobia. By its narrowly oblong outline, acute spire, nearly flattened whorls, and imperforate shell, it seems more closely related to Pleurocera. One of the well-preserved specimens measures $11.3 \mathrm{~mm}$. in altitude and $4.5 \mathrm{~mm}$. in width of the shell, $3.3 \mathrm{~mm}$. in height and $2.8 \mathrm{~mm}$. in width of aperture, and has the last 7 whorls preserved.

Plesiotype, U. S. Nat. Mus. 560176.

\section{Goniobasis nebrascensis (Meek and Hayden)}

\section{- $\quad$ Plate 10, figure 9}

Melania nebrascensis Meek and Hayden, Acad. Nat. Sci. Philadelphia Proc., vol. 8, p. 124, 1856.

This species was found only at one locality of the present collection, but it is represented by more than 80 specimens. It is characterized by its acute spire, dilated body whorl, scarcely convex whorls, and by having its basal lip margin somewhat produced. Judged by the features visible in this series of specimens, this form resembles more closely species of Goniobasis than those of Campeloma and Lioplax, although it may not be a Goniobasis in the restricted sense. One of the adult specimens measures $26.5 \mathrm{~mm}$. in altitude and $13 \mathrm{~mm}$. in width of the shell, $11.1 \mathrm{~mm}$. in height and $7.8 \mathrm{~mm}$. in width of aperture, and has the last 5 whorls preserved.

Plesiotype, U. S. Nat. Mus. 560177.

Goniobasis nebrascensis producta (White)

Plate 10, figure 10

Campeloma producta White, U. S. Nat. Mus. Proc., vol. 5, p. 97, pl. 3, figs. 7-9, 1883.

A few specimens seem to agree well with this form, which differs from the typical form of the species by its more elongate outline. However, it agrees well with the typical form in other features. One of the adult specimens measures $31 \mathrm{~mm}$. in altitude and $13.4 \mathrm{~mm}$. in width of the shell, $10.7 \mathrm{~mm}$. in height and $7.1 \mathrm{~mm}$. in width of aperture, and has the last 6 whorls preserved.

Plesiotype, U. S. Nat. Mus. 560178.

\author{
Family ANCYLIDAE \\ Ferrissia minuta (Meek and Hayden) \\ Plate 10, figure 14
}

Valletia (Ancylus) minuta Meek and Hayden, Acad. I'at. Sci. Philadelphia Proc., vol. 8, p. 120, 1856.

A few fairly well preserved specimens are identical with this species. It is characterized by its small size, ovate-oblong outline, anterior apex, which points toward the anterior margin, and fine but distinct concentric lines of growth with occasional undulations over the surface. The anterior right margin seems to be slightly contracted. The average-sized specimer measures $4 \mathrm{~mm}$. in length and $3 \mathrm{~mm}$. in width.

Plesiotypes, U. S. Nat. Mus. 560179.

Palaeancylus, n. gen.

Shell limpetlike, ovate in outline, of thin substance, and of moderate size in Ancylidae. Apex apparently sinistral, slightly coiled, subcentrally posterior in position, and having a distinct dimplelike def ression on the apical surface. The dimple is well-defined by an encircling margin. The sculpture consists of distinct but fine concentric lines of growth and radiating lines all over the surface.

Genotype: Palaeancylus radiatus, n. sp.

The new genus now under consideration is differentiated from most of the fresh-water limpets by a small dimplelike depression on its apical surface, which feature has been found on all the well-preserved specimens in the present collection.

The morphological significance of this apical depression is unknown, but it seems to be quite a distinct feature that has been ignored or taken as an individual abnormality by early investigators. In the living fauna, I have noted several species, such as Ancylus fuviatilis Mueller, Ancylus abissinicus Jickeli, Ancylus caliculatus Bourgguignat, and "Ferrissia" platyrhynchus Walker, described from southern Europe and northern Africa, which also bear this distinct feature, though differing in degree in its development. These species seem to belong to Pseudoancylus Walker 1921, with Ancylus fluviatilis as its genotype, from which Palaeancylus, $\mathrm{n}$. gen., of the Fort Union formation, differs by having an apparently sinistral apex, posteriorly contracted margin on the left side, and more distinct sculpture.

\section{Palaeancylus radiatus, n. sp. \\ Plate 10, figure 13}

Shell essentially the same as described for the genus. The radiating sculpture is stronger than the concentric lines; the apex is apparently sinistral, subcentrally posterior in position, somewhat nearer the left side of the peristomal margin, where the marginal line is somewhat contracted. The right side of the morgin is entire. 
The measurements in millimeters of the holotype and the paratype are as follows:

\begin{tabular}{l|r|r}
\hline Length of shell & 4.5 & 10.3 \\
Width of shell & 3.5 & 8.0 \\
\hline
\end{tabular}

Holotype, U. S. Nat. Mus. 560180; paratypes, U. S. Nat. Mus. 560181.

\section{Family LYMNAEIDAE}

Pleurolimnaea tenuicosta (Meek and Hayden)

Plate 10, figure 15

Limnaea tenuicosta Meek and Hayden, Acad. Nat. Sci. Philadelphia Proc., vol. 8, p. 119, 1856.

This species is so far known only from the Fort Union formation. A few well-preserved specimens were found at one locality of the present collection.

Both on morphological and on stratigraphical grounds, Pleurolimnaea Meek may well be considered as a distinct genus, but its family assignment may need further consideration. The genus may belong to Ellobiidae and is possibly related to Tortacella.

An adult specimen measures $13.1 \mathrm{~mm}$. in altitude and $4.5 \mathrm{~mm}$. in width of the shell, $6 \mathrm{~mm}$. in height and $2.2 \mathrm{~mm}$. in width of aperture, and has 5 whorls.

Plesiotype, U. S. Nat. Mus. 560182.

\section{Family PHYSIDAE}

Physa cf. P. bridgerensis Meek

Plate 10, figure 16

Physa bridgerensis Meek, Hayden Survey, 6th Ann. Rept., p. $516,1872$.

A few specimens seem to resemble closely Physa bridgerensis but differ by having smaller size, lower spire, and more whorls.

The largest specimen measures $27.5 \mathrm{~mm}$. in altitude and $17.1 \mathrm{~mm}$. in width of shell, $18 \mathrm{~mm}$. in height and $9 \mathrm{~mm}$. in width of aperture, and has about 6 whorls.

Figured specimen, U. S. Nat. Mus. 560183.

\section{Aplexa ef. A. longiuscula (Meek and Hayden)}

Plate 10, figure 17

Physa longiuscula Meek and Hayden, Acad. Nat. Sci. Philadelphia Proc., vol. 8, p. 119, 1856.

A few examples in the collection, which represent different stages of development, resemble closely this species, but they differ by having a more acute and higher spire, and they are of much smaller size, with a similar number of whorls. It may be a new species, but none of the available specimens show the aperture well enough for a satisfactory description. One of the adult specimens measures $11.5 \mathrm{~mm}$. in altitude and 6.1 $\mathrm{mm}$. in width and has 6 to 7 whorls.

Figured specimen, U. S. Nat Mus. 560184.
Family PLANORBIDAE

Gyraulus militaris (White)

Plate 10, figure 18

Planorbis militaris White, U. S. Nat. Mus. Proc., vol. 3, p. 159, 1880.

Only one lot in the present collection contains abundant specimens of this species, and in others it is represented by a few individuals. This species is often found in association with the next species, but it is easily distinguished by the absence of a carina on the basal surface and by a slightly larger size. One of the adult specimens measures $1.4 \mathrm{~mm}$. in altitude and 3 $\mathrm{mm}$. in width and has $3 \frac{1}{3}$ whorls.

Plesiotypes, U. S. Nat. Mus. 560185.

Gyraulus parvulus (Meek and Hayden)

Plate 10, figures 20, 20a

Valuata parvula Meek and Hayden, Acad. Nat. Sci. Philadelvhia Proc., vol. 8, p. 123, 1856.

This species is recorded from four localities in the present collection. It is one of the very few speries described by Meek and Hayden without a figure of the type. However, it was originally described as "having near the middle of the upper and lower sides a distinct linear carina," a feature which is well shown in the specimens in the present collection. One of the adult specimens measures $1 \mathrm{~mm}$. in altitude and $3 \mathrm{~mm}$. in width and has about 3 whorls.

In 1935 Henderson (Geol. Soc. America Spec. Pr ver 3, p. 191) followed Cossnran (Essais de paléoconchologie comparée, livr. 12, p. 170, 1921) in changing the name of this species to Valvata subparvula, because V. parvula had been used by Deshayes for a Thanetian speries from France. By examining the original citatior. of both species, I am obliged to point out that Cossmann's change cannot be sustained. Meek and Hayden proposed the name in May 1856 and published it some time between June 1856 and April 1857; whereas Deshayes' name appeared on page 526 , volume 2 , of his "Descriptions des animaux sans vertèbres du Bassin de Paris," which was not published until May 1862. The name proposed by Meek and Hayden has ample priority over that of Deshayes, and the French species is here renamed Valvata deshayesi, new name.

Plesiotypes, U. S. Nat. Mus. 560186.

Carinorbis planospiralis Yen

Plate 10, figure 19

Carinorbis planospiralis Yen, Am. Jour. Sci., vol. 224, No. 1, p. 46, pl. 1, figs. 6a-c, 1946.

This species is one of the characteristic forms of the Fort Union formation, although it is recorded from only six localities in the present collection. It is easily recognized by its carinated outline and nearly flattened spire. One of the adult specimens measures $2.1 \mathrm{~mm}$. 
in altitude and $4.4 \mathrm{~mm}$. in width of the shell, $2 \mathrm{~mm}$. in height and $1.2 \mathrm{~mm}$. in width of aperture, and has 4 whorls.

Plesiotype, U. S. Nat. Mus. 560187.

\section{Family SPHAERIIDAE}

Sphaerium cf. S. formosum (Meek and Hayden)

Plate 10, figure 21

Cyclas formosa Meek and Hayden, Acad. Nat. Sci. Philadelphia Proc., vol. 8, p. 115, 1856.

A few specimens from one lot of the present collection resemble this species in general outline, though the hinge structure is not observable. In another lot are three left valves that show the hinge line slightly curved, with two short, parallel cardinals and single anterior and posterior laterals. The posterior lateral is long and slightly truncated in the middle and moderately raised at its end; the anterior lateral is short and is terminated by a prominent tooth of triangular shape.

Figured specimen, U. S. Nat. Mus. 560188.

\section{Family UNIONIDAE}

Elliptio cf. E. priscus (Meek and Hayden)

Plate 10, figures 22, 22a

Unio priscus Meek and Hayden, Acad. Nat. Sci. Philadelphia Proc., vol. 8, p. 117, 1856.

Specimens from several localities in the present collection externally resemble this species closely.

The structure of the hinge was not described in the original description. One lot in the present collection contains a large series of single valves that show the hinge plate to be narrow, with two pseudocardinals and two laterals in the left valve; one prominent pseudocardinal and one lateral in the right valve. The anterior muscular impression is of subtriangular shape and large size.

Figured specimens, U. S. Nat. Mus. 560189.

\section{Elliptio cf. E. silberlingi Russell}

Plate 10, figures $23 \mathrm{a}, \mathrm{b}$

Elliptio silberlingi Russell, Washington Acad. Sci. Jour., vol. 24, p. 128, figs. 1, 2, 1934.

This form differs from the preceding species by its more elongate outline, less prominent pseudocardinals, and shorter laterals on both valves, but their number and arrangement are essentially similar.

The specimens in the present collection are much smaller in size than the type, which was described from the Eagle coal mine, Bear Creek, Carbon County, Mont.

Figured specimens, U. S. Nat. Mus. 560190.

“Unio"' sp. undet.

Plate 10, figure 24

Several specinens were obtained from localit: 6 that are decidedly different from other Unios in the collection but are not sufficiently well preserved to permit generic or specific identification. They are characterized by an almost lanceolate outline and are rather pointed toward the posterior end. The valves are closed.

Figured specimen, U. S. Nat. Mus. 560191.

\section{BIBLIOGRAPHY}

BAKER, A. A., The northward extension of the Sher'dan coal field, Big Horn and Rosebud Counties, Mont.; U. S. Geol. Suvey Bull. 806-B, 1929.

Brown, R. W., The age of the Kingsbury conglomerate is Eocene: Geol. Soc. America Bull. (in press).

C'ossman, Maurice, Essais de paléoconchyliologie comparée, vol. $12,1921$.

Henderson, Junius, Fossil nonmarine Mollusea of North America: Geol. Soc. America Spec. Paper 3, 1935.

Мекк, F. B., A report on invertebrate Cretaceous and Tertiary fossils of the upper Missouri country: U. S. Geol. and Geog. Survey Terr. Repts., vol. 9, 1876.

Meeк, F. B., and HaYden, F. V., Descriptions of new species of Acephala and Gastropoda, from the Tertiary formations of Nebraska Territory: Acad. Nat. Sci. Philadelphia Proc., vol. 8, pp. 111-126, 1856.

- Descriptions of new species and genera of fossils, collected by Dr. F. V. Hayden in Nebraska Territory: Acad. Nat. Sci. Philadelphia Proc., vol. 9, pp. 117-148, 1857.

RUsseld, L. S., Early Tertiary Mollusca from Wyoming: Am. Paleontology Bull., vol. 18, No. 64, 1931.

SpIEKer, E. M., Late Mesozoic and Early Cenozoic ristory of central Utah: U. S. Geol. Survey Prof. Paper 205-D, 1946.

Tном, W. T., JR., and Doвbin, C. E., Stratigraphy of the Cretaceous-Eocene transition beds in eastern Montana and the Dakotas: Geol. Soc. America Bull., vol. 35, pp. 495-496, 1924.

WEED, W. H., The Fort Union formation: Am. Geologist, vol. 18, No. 4, pp. 201-211, 1896.

Wegeman, C. H., Wasatch fossils in so-called Fort Union beds of the Powder River Basin, Wyo., and their bearing on the stratigraphy of the region: U. S. Geol. Survey Prof. Prper 108, pp. 57-60, 1918.

White, C. A., On the relation of the Laramie molluscan fauna to that of the succeeding fresh-water Eocene and other groups: U. S. Geol. Survey Bull. 34, 1886.

Yes, Teng-Chien, Paleocene fresh-water mollusks from Sheridan ('ounty, Wyo.: Am. Jour. Sci., vol. 224, pp. 41-48, 1946.

- Focene nonmarine gastropods from Hot Springs County, Wyo.: Jour. Paleontology, vol. 20, No. 5, pp. 495-5?0, 1946. 
PLATE 10 


\section{PLATE 10}

FIGURe 1. Viviparus raynoldsanus (Meek and Hayden). Locality 24

2. Viviparus trochiformis (Meek and Hayden). Locality 25

3. Viviparus retusus (Meek and Hayden). Locality $39 \ldots \ldots$

4, 5. Campeloma nebrascensis (Meek and Hayden). 4, 4a, Locality 42. 5, 5a, 5b, Locality 43

6. Lioplacodes mariana Yen, X 2. 6, Locality 7. 6a, Locality 35. 6b, Locality 40_.................... 41

7. Lioplacodes tenuicarinata (Meek and Hayden), X 2. 7, 7a, Locality 24. 7b, 7c, 7d, Locality $40 \ldots$

8. Pleurocera warrenanum (Meek and Hayden), X 2. Locality 13

9. Goniobasis nebrascensis (Meek and Hayden), X 2. Locality $42 \ldots$

10. Goniobasis nebrascensis producta (White), X 2 . Locality $42 \ldots$

11. Lioplacodes limnaeiformis (Meek and Hayden), $\mathrm{X} 2$. Locality

12. Fluminicola protea Yen, n. sp. holotype, X 2 . Locality 17

13. Palaeancylus radiatus Yen, $n$. gen. and sp., holotype, $X 10$. Locality 17

14. Ferrissia minuta (Meek and Hayden), X 10 . Locality 17

15. Pleurolimnaea tenuicosta (Meek and Hayden), X 2. Locality 17

16. Physa ef. P. bridgerensis Meek. Locality 17

17. Aplexa ef. A. longiuscula (Meek and Hayden), X 2 . Locality 17

18. Gyraulus militaris (White), $\mathrm{X} 4$. Locality $29 \ldots$

19. Carinorbis planospiralis Yen, $\mathrm{X} 4$. Locality $12 \ldots$

20. Gyraulus parvulus (Meek and Hayden), X 4. Locality 29 43

21. Sphaerium ef. S. formosum (Meek and Hayden), X 4 . Locality $42 \ldots$

22. Elliptio cf. E. priscus (Meek and Hayden). Locality 29

23. Elliptio cf. E. silberlingi Russell. Locality 29

24. Unio sp. undetermined. Locality $6 \ldots$ 


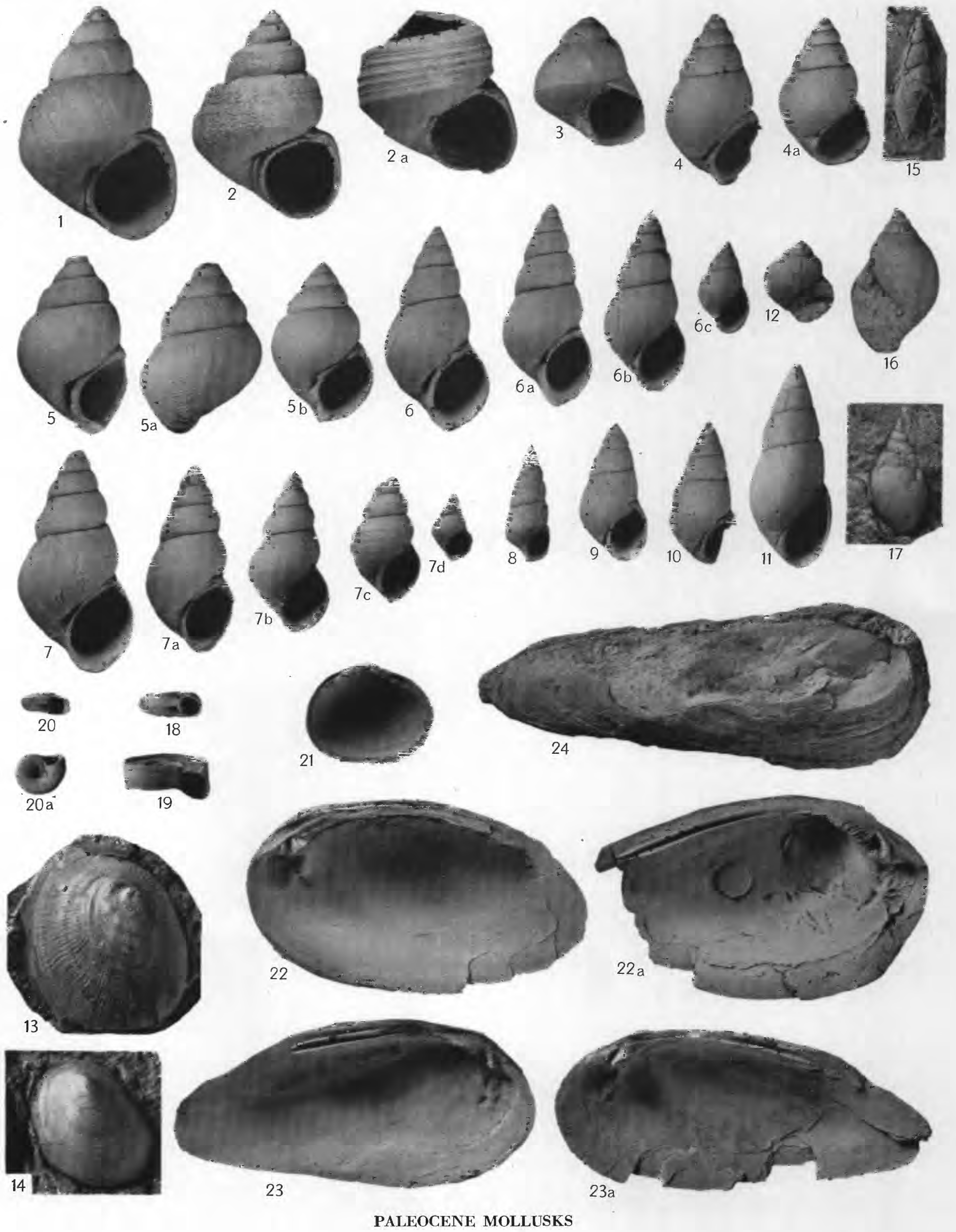





\section{N D E X}

abissinicus, Ancylus.

Acknowledgments for aid

Ancylus abissinicus. caliculatus fluviatilis.

anthonyi, Melania

Aplexa. longiuscula

Bibliography

Big Horn County, fossils from

bridgerensis, Physa

ulimus limnaeiformis . . . . nebrascensis $\ldots$

caliculatus, Ancylus.

Campeloma

(25, 42 nebrascensis ................. $36,37,40,41$, p1. 10 producta.

Carinorbis

Crazy Mountains, mollusks from

Cyclas formosa.

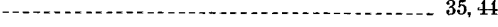

deshayesi, Valvata

Elliptio priseus . . . $36,37,38,39,40,44$, pl. 10

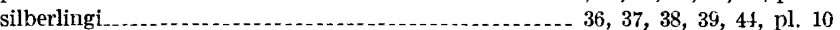

eulimoides, Hydrobia

Ferrissia minuta platyrhynchus

Finminicola

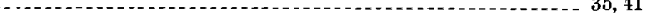

$36,38,41, \mathrm{pl} .10$

fluviatilis, Ancylus

formosa, Cyclas

formosum, Sphaerium.

formosus, Viviparus leidyi

Fort Union formation, age of . 37 mollusks from

Fossil collections, geographic distribution of . . . . . . source of

$35,37,42$

Goniobasis nebrascensis nebrascensis producta................................... 36

Gyraulus. militaris. $36,38,39,40,43$, pl. 10 parvulus. . .

Hydrobia eulimoides

Hyracotherium.

insculpta, Melania

Kingsbury conglomerate, age of

leai, Paludina

leidyi, Paludina.

Lignite group, mollusks from

Limnaea tenuicosta

limnaeiformis, Bulimus Lioplacodes

Lioplacodes.

limnaeiformis................. . . $36,37,48,39,40,41, \mathrm{pl} 10$

mariana.

$36,37,38,39,40,41, \mathrm{pl} .10$

tenuicarmata
Lioplax

nebrascensis

Pag ?

longinscula, Aplexa. ... Physa mariana, Lioplacodes $\ldots \ldots \ldots . . .36,37,38,39,40,41, \mathrm{pl} .1$ \}

Melania

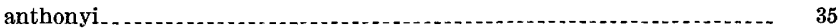

insculpta.

minutula

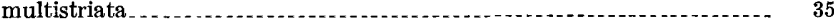

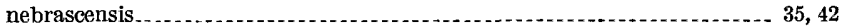

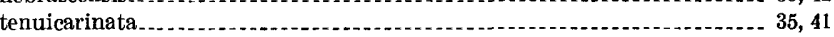

warrenana

militaris, Gyraulus $\ldots \ldots \ldots . . . .36,38,39,40,43$, pl. 19

Planorbis..

$36,38,39,40,43$, pl. 1 ?

$36,37,38,42$, pl. 1 ?

Valletia (Ancylus) $\ldots \ldots \ldots \ldots \ldots \ldots$

minutula, Melania

Mollusks, age of

earliest records of

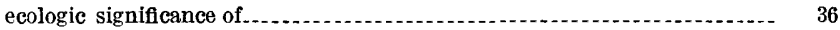

species of, summary of .

stratigraphic distribution of

montanaensis, Valvata__... 35

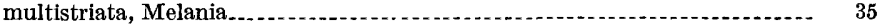

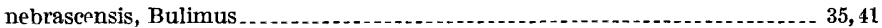

Campeloma

Goniobasis ........... $36,37,40,41,42$, pl. 10

Lioplax.

41

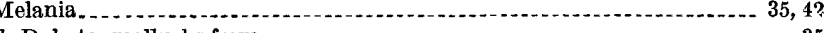

North Dakota, mollusks from . . . .

Palaeancylus $\ldots$

radiatus ......

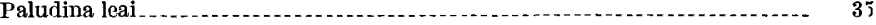

leidyi ......... 35

peculiaris

retusa $\ldots$

trochiformis . . .

parvula, Valvata $\ldots . . . . . . . . . . . . . . .35,43$

parvulus, Gyraulus........... $36,38,39,40,43$, pl. 17

peciliaris, Paludina.

Physa

bridgerensis . . . .

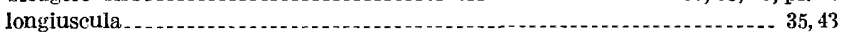

rhomboidea.. ...... 35

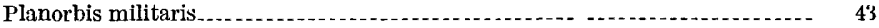

planospiralis, Carinorbis............................ 36, 37, 38, 39, 43-44, pl. 1)

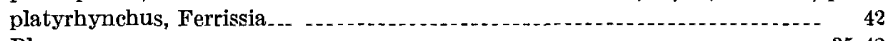

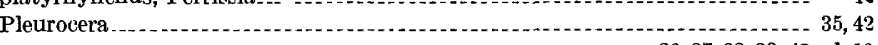

warrenanum. . .

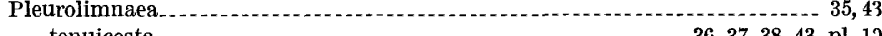

tenuicosta $\ldots \ldots \ldots . . .36,37,38$, pl. 17

Powder River County, fossils from

priscus, Elliptio

Unio

producta, Goniobasis nebrascensis.
protea, Fluminicola

Pseudoancylus_.......... 42

radiatus, Palaeancylus

$36,38,42-43$, pl. 13

raynoldsana, Vivipara...............

raynoldsanus, Viviparus $\ldots \ldots \ldots . .36,37,38,39,40$, pl. 11

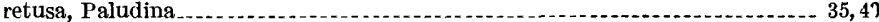

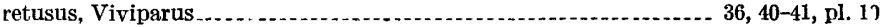

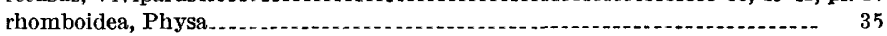

Roland coal bed, mollusks from

Rosebud County, fossils from 
Page

silberlingi, Elliptio

$36,37,38,39,44, \mathrm{pl} .10$

Sphaerium

formosum .

sp.-

subellipticus, Cyclas

subparvula, Valvata

sułumbilicata, Valvata

tenuicarinata, Lioplacodes Melania

$36,37,38,39,40,41$, pl. 10 Cimnaea.

..... - . 35,43

Pleurolimnaea

$36,37,38,43$, pl. 10

thompsoni, Tulotoma

Tongue River member and Wasateh formation, boundary between

Tortacella.

trochiformis, Paludina

35,40

Viviparus................... $36,37,38,40,010$

Tulotoma thompsoni.

Unio priseus... . . . . . . . . . . . .

spp $\ldots \ldots \ldots \ldots \ldots \ldots$

Utah, mollusks from
Valvata deshayesi. . . .

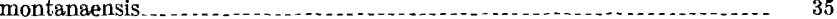

parvula

subparvula.................... 43

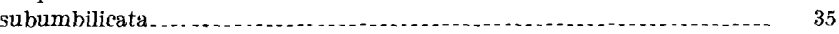

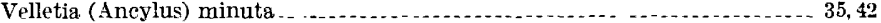

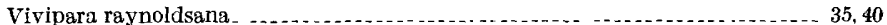

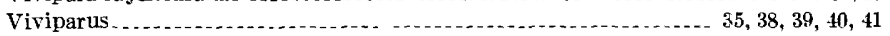

Viviparus leidyi formosus raynoldsanus.......................................... 36, 37, $38,39,40$, pl. 10

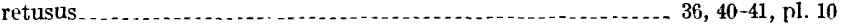
trochiformis . . . . sp . . . .

warrenana, Melania ...........

warrenanuin, Pleurocera................................ 36, 37, $88,39,42$, pl. 10

Wasatch formation and Tongue River member, boundary between .......... $36-37$

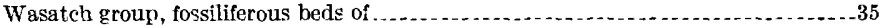

Wyoning, mollusks from _..........

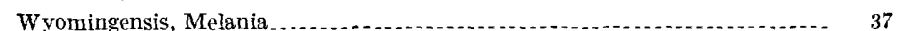

